\title{
Affective Engagement of Higher Education Students in an Online Course
}

\author{
Wajeeh Daher ${ }^{1,2 *}$, Kifaya Sabbah ${ }^{1}$, Maysa Abuzant ${ }^{1}$ \\ ${ }^{1}$ An-Najah National University, Nablus, Palestine \\ ${ }^{2}$ Al-Qasemi Academic College of Education, Baqa El-Garbiah, Israel
}

\begin{abstract}
The present research studies the factors that have impacted the affective engagement of university students in an educational online course. It examines how the type of interaction (learner-learner, learner-instructor, and learner-content) and the type of engagement (behavioural, cognitive and affective) have influenced the affective engagement of the students in the online course. Nineteen university students majoring in teaching mathematics, who were enrolled in the course Mathematics Teaching Methods, participated in the present research. Two data collection tools were used: semi-structured interviews and reflections. To analyse the texts resulting from the interviews and reflections, inductive and deductive qualitative content analysis was used. The research results indicated that university students have experienced more positive than negative affective engagement in the three communicational channels used in this course to facilitate online learning, which were: synchronous lectures, forums and assignments. The results also indicated that these three types of interaction have positively influenced students' affective engagement in the three channels, with that influence being different from one channel to the other based on the interaction type taking place. We suggest that specific types of engagement need to be attended to for positive affect to occur.
\end{abstract}

\section{Keywords:}

Interaction Types;

Engagement Types;

Online Courses;

University Students.

\section{Article History:}

$\begin{array}{llll}\text { Received: } & 17 & \text { May } & 2021 \\ \text { Revised: } & 11 & \text { July } & 2021 \\ \text { Accepted: } & 22 & \text { July } & 2021 \\ \text { Published: } & 01 & \text { August } & 2021\end{array}$

\section{1- Introduction}

Student engagement has attracted the attention of researchers as it can positively influence the different aspects of students' learning, such as critical thinking [1], cognitive development [2], moral \& ethical development [3], student satisfaction [4], and persistence [5]. More specifically, researchers are interested in student engagement in online classrooms, as these classrooms are flourishing due to their ability to maintain a high engagement level of both the instructors and the students in the educational process in different contexts and under various circumstances. One such context is that of COVID-19 that has made the use of online classrooms a must due to imposing social distancing restrictions which turned the regular classroom into a health hazard for students and instructors.

In the case of this research, we aimed to examine the affective engagement of pre-service mathematics teachers enrolled in the course Mathematics Teaching Methods. The course covered arrange of topics and issues including critical thinking, democracy, and metacognition in the mathematics classroom. Students were asked to discuss these topics and issues, engage in writing activities that tackle them, and self-evaluate these activities. The course was delivered to students online, through the use of three main channels: synchronous lectures, online assignments, and forums. Little research has addressed students' engagement in the mentioned three channels. The present research attempts to do so.

\footnotetext{
${ }^{*}$ CONTACT: daherwajeeh@gmail.com
}

DOI: http://dx.doi.org/10.28991/esj-2021-01296

(C) 2021 by the authors. Licensee ESJ, Italy. This is an open access article under the terms and conditions of the Creative Commons Attribution (CC-BY) license (https://creativecommons.org/licenses/by/4.0/). 
Unfortunately, and as with all research, this research endeavor is faced with a number of limitations. First, it is limited by its sample - nineteen students and by the discipline, as it addresses a specific type of educational courses, which is teaching methods. Second, is limited by its assumptions. One of those assumptions is that content analysis could be successful when analyzing the texts of nineteen students. This assumption relies on the high number of units of analysis that students' texts raise, which enables us to study the related phenomenon. A second assumption is that the frequencies and percentages of themes related to an educational phenomenon could give a picture about this phenomenon. This assumption relies on researchers' emphasis that frequency and percentages could give a picture of the social phenomenon [6]. A third assumption is that interactions and engagement could be studied together. This assumption relies on studies considered the two phenomena as two facets of the same phenomenon, which is engagement [7].

Following, we first present the literature review related to the present research. This literature review describes students' engagement and its different aspects: Facilitators of engagement, students' perception of their engagement, indicators of engagement, engagement and educational technology in higher education and engagement in distance learning as interaction. Second, we elaborate on the research rationale, goals and questions, and third we present the methodology of the research. Fourth we present our findings and discussion and fifth the research conclusions.

\section{2- Literature Review}

Although student engagement has attracted the attention of researchers for decades [8,9], there is still no complete commonality on an exact definition for that term [10,11]. In a review of studies tackling student engagement, Bond et al. [12] reported that only $\% 7$ of the reviewed studies attempted to define student engagement. On the other hand, and in an attempt to set some guidelines for defining the construct of engagement, Axselson and Fleck [13] emphasized the importance of distinguishing between two uses of the term. The first one is engagement being as a measure of the learning process, and the second as an antecedent or predictor of student behaviour during a given learning process. This indicates that engagement could be a predictor or an outcome. In this research, we consider it as being both, as one type of engagement could be the predictor of another, or the same type could be a predictor and outcome.

Despite the lack of a unified terminology, there seems to be an agreement on that engagement is a multifaceted concept [14] that goes beyond mere academic engagement time, to include the affective, behavioural, and cognitive traits of students [15]. Behavioural engagement is viewed in terms of the time and effort a student spends in learning [16] and doing activities in an effort to learn [11], utilizing attention, participation, and effort [19]. This type of engagement is deemed as a powerful indicator of students' educational outcomes [18]. Affective Engagement, on the other hand, encompasses students' emotions towards the learning process, context, peers and teachers, whether negative or positive [18], as well as their sense of belonging [19]. Finally, cognitive engagement reflects the level of students' engagement in an activity, or a task, in terms of thinking how to approach it [13]. In recent research, Bond et al. [12] has defined engagement, reflecting those 3 dimensions, as: "The energy and effort that students employ within their learning community, observable via any number of behavioural, cognitive, or affective indicators across a continuum".

Studies have shown that engagement has a positive impact on students' academic achievements [20], grades and persistence [5], as well as retention and better learning [5, 21]. Moreover, engagement gives students a sense of belonging and connectedness [22], as well as, not only decreasing the chances of dropout rates but also increasing the rates of successful school completion [15]. In online courses, student engagement is more crucial as it plays a central role in stimulating students learning [23], and establishing interaction opportunities for the students with the institution [24].

\section{2-1- Facilitators of Engagement}

In order to improve students' success, there is a need to grasp how different factors interact and influence student engagement [25]. Reschly and Christenson [15] refer to the contextual factors that affect engagement as facilitators of engagement. While Skinner and Pitzer [22], with their motivational model lens on engagement, break down these factors into personal and social facilitators. Personal facilitators include students' self-perception and self-appraisals, such as self-efficacy. Social facilitators refer to the nature of interpersonal interactions that the students have with teachers, peers, and parents. In the present research, we consider the interactions occurring in three of the communication channels of online learning; i.e. the synchronous lectures, the assignments and the forums, in order to examine their influence on students' affective engagement.

In an agreement with Skinner and Pitzer [22], Kahu and Nelson [23] have also categorized facilitators into those related to the students' themselves, such as motivation and personality, and others relating to their context such as background, culture, family and support. However, Kahu and Nelson [23] have gone beyond in proposing a framework in which they introduce the notion of an educational interface. This interface refers to the area where students (with their context), interact with their higher education institutional structural influences. An alignment in students and institutional influences will cause engagement to occur. This engagement is usually mediated by four psychosocial constructs which include students' self-efficacy, emotions, belonging and wellbeing. 


\section{2-2- Students' Perception of their Engagement}

In the aforementioned framework, Kahu and Nelson [25] have recognized the active role students' play in their engagement, by drawing attention to the importance of students' perception of their own engagement and interaction with their context, and its influence on the level of engagement; students' perception of their engagement could increase or decrease their level of engagement. Haug et al. [26] reported that students' feeling of connectedness and belonging to course content is evident to enhance engagement, which increases overall student satisfaction. They have also reported that students perceive working on real-life tasks as a strategy that increases their level of engagement. This is also echoed in a study done by Martin \& Bollinger [24] regarding students' engagement in online courses. They reported that students perceive the varied aspects of an online course differently, with their perception of the learner-instructor interaction ranking high on what affects their engagement with the course. Another added benefit to students' perception of their own engagement is that it allows getting a deeper insight into the reasons behind a certain activity being more or less engaging [27]. This is of importance for this present study as we are aiming to investigate how different online communication channels could affect engagement differently.

\section{2-3- Indicators of Engagement}

To measure student engagement, a number of indicators have been used in the literature. Indicators refer to the "descriptive parts inside a target construct" [22]. They are viewed in terms of their valance (positive or negative), as well as being high or low [28]. The most-reported indicators of engagement are participation, interaction, and achievement [12]. Other engagement indicators include behavioural engagement indicators, such as task involvement, effort, persistence, attention, and retainment, cognitive engagement indicators such as self-regulation, and finally emotional engagement indicators such as happiness, enthusiasm, interest, confidence, enjoyment, satisfaction, and pride [29].

Other types of indicators could be used to measure disengagement, whether emotional such as negative emotions like boredom, lack of interest, frustration and anger, sadness, and anxiety $([30,31])$, or behavioural such as being passive, giving up, withdrawal, distraction, and burnout [29], and finally Cognitive disengagement which could include little use of thinking processes or self-regulation processes.

\section{2-4- Engagement and Educational Technology in Higher Education}

Lately, higher education institutions have been under significant pressure to increase retention and graduation rates from online courses [32]. This pressure has multiplied in the past few months since many higher education institutions were forced to make a sudden shift to online learning due to Covid-19 outbreak [33]. The use of educational technology in the instructional process has been linked to an increase in student engagement [34]. At the same time, measuring the level of students' engagement is necessary for online learning as evidence of its success in making learning happen and achieving its goals [24]. In a synthesis of the literature on the use of technology and student engagement in higher education, Bedenlier et al. [34] have found out that behavioral engagement plays a major role in students' engagement, while affective disengagement is the most prominent dimension leading to the student not attaining the intended learning outcomes of the course. At the same time, research has evidenced that the use of technology has been linked to an increase in some of the indicators of engagement [35] which include interest, enjoyment, improved confidence, attitudes, and enhanced relationships with peers and teachers.

With that being said, technology alone cannot promote students' engagement, it has to be accompanied with proper planning and a choice of the right technological tools to fit the course [12], otherwise it can promote disengagement and hinder learning [36]. Nevertheless, Howard et al. [36] attest that this choice is usually an outcome of the teachers' assessment of students' digital efficacy, and the tool's potentials to engage learners. However, with the course structure evidenced to influence how students deal with the content of the course and the social interactions in it [37], careful thought needs to be put in choosing the technological tools used to deliver the course content. Bond et al. [12] reported that the most used tools in online engagement studies, that have a significant impact on engagement, are text-based tools. Moreover, researchers have focused mainly on the role LMS, discussion forums, recorded lectures and chat play in students' engagement. This research adds to the literature by focusing on the role synchronous lectures play in inflecting students' engagement.

\section{2-5- Engagement in Distance Learning as Interaction}

A key factor in engaging students with these tools is the establishment of a presence in the online environment [38]. Students' perception of their presence is related to the interactions they have with the other students and their instructor. Focusing on the role interaction plays in engaging students in distance education Bernard et al., [39] have proposed 3 types of interaction: student-student interaction, student-content interaction, and student-teacher interaction. Studentstudent interaction includes student interaction with individual students or in small groups, in a synchronous and asynchronous manner. This type of interaction motivates students and evokes social presence; it also aims to create a sense of community for the learners [24]. Studies have reported that tools such as discussion boards, chat rooms, blogs, and group tasks, work well when aiming to enhance student-student interaction [23]. 
Student-instructor interaction takes place during the instructional process between the students and their teacher, and it is part of the need to establish a teaching presence [24]. It aims at keeping students interested in the content being presented and to provide them with any needed support. Instructors are recommended to utilize different channels of communication with their students [23]. However, their level of involvement with these channels needs to vary based on the level of engagement intended to be evoked from the learners. For example, online discussion forums are reported as the most effective tools used to engage learners $[40,24]$. Nevertheless, it is recommended that teachers are minimally active with forum discussions [41] to give students a chance to interact with each other.

Finally, student-content interaction refers to the way students interact with the subject matter and the material being presented. The design of the content and the course is important to engage learners and establish the cognitive aspect of learning [38]. It is important for course activities to be structured and clear to understand [24, 38], and designed in a way to invoke inquiry and exploration [42].

\section{3- Research Rationale and Goals}

Engagement in online learning is an emerging variable that affects the different aspects of students' learning and thus affecting their achievement and classroom well-being. Researchers have proposed the existence of a mutual relationship between students' context and their level of engagement [43]. Specifically that students' affective engagement, such as their sense of belonging and school connectedness, could influence and be influenced by other variables of students' learning. In the present research, we study the affective engagement of university students in the three delivery channels of an online course: synchronous lectures, assignments and forums. Doing that, we address the conditions of positive and negative affective engagement by looking at two aspects of these conditions: the type of interaction (learner-learner, learner-instructor and learner-content) and the type of engagement (behavioral, cognitive and affective).

In a review of studies on the topic of the engagement of higher education students in online courses using educational technologies, Bond et al. [12] has emphasized that the reviewed studies often focused on individual facets of students' engagement, which highlights the importance relating "these individual facets to the larger framework of student engagement, by considering how these aspects are connected and linked to each other". They further emphasize that it is not enough to focus only on one facet of engagement, but also to look at facets that are adjacent to it. This is what the present research attempts to do, by considering the occurrences of interaction and engagement types as conditions for a specific engagement type.

To study the conditions of the affective engagement of university students in the online course, we use interviews and students' reflections on their experience in the three channels of delivery in the course. This enables us to target the affective engagement in online courses from a new angle. Researchers have argued that the use of quantitative methods to evaluate online learning is questionable [44, 45], making studies that follow the qualitative methods more reliable. Very little qualitative research methods were employed in engagement research [12], where the present research attempts to do so. It does that by using interviews and students' reflection texts as data collection tools, which would reveal the quality and quantity of interaction and engagement; and thus shedding more light on the relatedness of both sides. In addition, employing a qualitative method of inquiry meets the calls of researchers to consider not only the quantitative aspect of interaction but the qualitative aspects too, because of its potential to clarify the processes of interaction [46, 47]. In the present research, we use qualitative as well as quantitative research method to study university students' engagement in online learning. The qualitative method is applied to discover themes related to the phenomenon [48], while the quantitative method is applied to describe the findings through frequencies and percentages [6].

\section{3-1- Research Questions}

\section{First Research Question:}

What interaction type (learner-learner, learner-instructor, and learner-content) manifested in the communicational channels of the online course influence both positively and negatively the affective engagement of university students in the course?

\section{Second Research Question:}

What engagement type (behavioral, affective, and cognitive) manifested in the communicational channels of the online course that influence both positively and negatively the affective engagement of university students in the course?

\section{4- Methodology}

\section{4-1- Research Paradigm}

The present research lies within the content analysis paradigm, both qualitative and quantitative. The qualitative aspect lies in trying to characterize the studied phenomenon by characteristics emerging from the constant comparison 
method that is applied over the data [48]. The quantitative aspect lies in finding frequencies and percentages of each category related to the studied phenomenon [6].

\section{4-2- Research Setting and Participants}

Nineteen university students participated in the present research. These students studied for their M.A. degree in mathematics teaching and were enrolled in the course 'Mathematics Teaching Methods'. The course covered a number of topics including critical thinking in the mathematics classroom, democracy in the mathematics classroom, and metacognition in the mathematics classroom. At the beginning of the course, meetings were face-to-face in a regular classroom setting, during which the first topic 'critical thinking' was covered. Each one of the face-to-face meetings consisted of four parts: a very short presentation of the new topic by the instructor, answering in groups 2-4 questions given by the instructor, whole-class discussion of the answers, which begins with the group presentation of ideas raised in the group's discussion, and finally, generalizations were drawn from the whole-class discussions and based on appropriate literature. Towards the middle of the course, the meetings had to be moved online due to COVID-19 outbreak. Both synchronous and asynchronous delivery channels were employed to facilitate online learning, however, the structure of the synchronous meeting remained the same as the face-to-face meeting with its 4 parts division.

\section{4-3- Data Collection Tools}

Two data collection tools were employed for the purpose of this research: interviews and students' reflections. The interviews were semi-structured and included questions such as: describe how you were engaged in online learning? What did you like in this type of learning? What did you dislike?

In the reflections, the students were asked to answer the following questions: (1) Reflect on your engagement in the synchronous lecture detailing both the positive and the negative experiences (3) Reflect on your engagement in the online forum detailing both the positive and the negative experiences, (4) Reflect on your engagement in the online assignments detailing both the positive and the negative experiences.

\section{4-4- Data Analysis Tools}

To analyze the data resulting from the interviews and reflections, we employed both inductive and deductive qualitative content analysis. Content analysis is a process of categorizing a text into categories/themes based on inferences and interpretations related to a social/educational phenomenon by using inductive reasoning. Deductive reasoning, on the other hand, is used to generate concepts based on a theoretical framework [49]. Employing the deductive reasoning has enabled us to look for themes related to specific engagement frameworks as that in Bolliger and Martin [50] who viewed engagement as interaction patterns, and that of Fredricks et al. [18] who identified engagement as constituting of three types: behavioural, cognitive and affective. Whereas, inductive reasoning has helped us in exploring a wider range of engagement themes/categories that were not described in the literature.

Table 1 describes the categories, themes and examples on each theme according to Bolliger and Martin [47], while Table 2 describes the categories, themes and examples on each theme according to Fredricks et al. [18].

Table 1. Categories, themes and indicators for each theme according to Bolliger and Martin.

\begin{tabular}{|c|c|c|}
\hline Category & Themes & Indicators \\
\hline \multirow{3}{*}{$\begin{array}{l}\text { Learner-learner } \\
\text { interaction }\end{array}$} & Discussion & Discuss an idea with another learner, argue regarding another learner's claim; \\
\hline & Sharing of experiences and ideas & $\begin{array}{l}\text { Give another learner an example from previous experience, expresses an idea } \\
\text { to another student; }\end{array}$ \\
\hline & Collaboration with peers & $\begin{array}{l}\text { Collaborate with another learner in solving a problem, collaborate with another } \\
\text { learner in pres3enting an idea; }\end{array}$ \\
\hline \multirow{3}{*}{$\begin{array}{l}\text { Instructor-learner } \\
\text { interaction }\end{array}$} & $\begin{array}{l}\text { Instructors can support and } \\
\text { encourage student participation }\end{array}$ & $\begin{array}{l}\text { Instructor goes to the group to encourage them to continue solving the problem } \\
\text { despite its difficulty, instructor approaches a student to advance her problem } \\
\text { solving; }\end{array}$ \\
\hline & Instructors provide timely feedback & $\begin{array}{l}\text { Instructor goes to the group to give them directions that help them advance } \\
\text { further in their discussion, instructor gives feedback to a student regarding the } \\
\text { solving of a problem; }\end{array}$ \\
\hline & $\begin{array}{l}\text { Instructors set expectations for the } \\
\text { course }\end{array}$ & $\begin{array}{l}\text { Instructor describes what is expected from the group's discussions, instructor } \\
\text { describes what is expected from a project. }\end{array}$ \\
\hline \multirow{2}{*}{$\begin{array}{l}\text { Learner-content } \\
\text { interaction }\end{array}$} & Engages with instructional materials & Reads a paper from the course's materials, solves a problem; \\
\hline & Spends time on content & Spends time on reading a paper, spends time on solving a problem. \\
\hline
\end{tabular}


Table 2. Categories, themes and indicators for each theme according to Fredricks et al.

\begin{tabular}{cll}
\hline Category & \multicolumn{1}{c}{ Themes } & Examples \\
\hline $\begin{array}{c}\text { Behavioral } \\
\text { Engagement }\end{array}$ & $\begin{array}{l}\text { Adhering to classroom norms } \\
\text { Involvement in learning and academic tasks }\end{array}$ & $\begin{array}{l}\text { Behave according to the norms set by the teacher, } \\
\text { Effort, contributing to class discussion }\end{array}$ \\
\hline $\begin{array}{c}\text { Emotional } \\
\text { Engagement }\end{array}$ & Positive emotions & Interest, happiness, \\
& Negative emotions & Boredom, sadness, \\
Cognitive & Problem solving & $\begin{array}{l}\text { Solving a problem, expresses preference for a solution of a } \\
\text { problem; }\end{array}$ \\
& Understanding and mastering the knowledge & $\begin{array}{l}\text { Understand the learning material, discusses the learning } \\
\text { material, }\end{array}$ \\
& Acquiring skills & Develop a cognitive skill, develop a metacognitive skill \\
\hline
\end{tabular}

\section{5- Results and Discussion}

The present research aimed at examining the effect that online interaction and engagement types manifested in 3 different communicational channels (synchronous lectures, assignment and forums) have on students' affective engagement level. The research results indicated that interaction and engagement types influence both positively and negatively students' affective engagement manifested the three communicational channels. We elaborate more on these findings in the below section.

\section{5-1- Synchronous Lectures}

Table 1 and Table 2 show examples of occurrences that resulted in positive and negative affective engagement in the synchronous lectures, respectively.

Table 3. Occurrences in the synchronous lectures that resulted in positive affective engagement

\begin{tabular}{|c|c|c|c|}
\hline & $\begin{array}{l}\text { Interaction between the learner } \\
\text { and other learners }\end{array}$ & $\begin{array}{l}\text { Interaction between the learner } \\
\text { and the teacher }\end{array}$ & $\begin{array}{c}\text { Interaction between the learner } \\
\text { and content }\end{array}$ \\
\hline Behavioural & $\begin{array}{l}\text { Being happy: a student praising of } \\
\text { another student's ideas }\end{array}$ & $\begin{array}{l}\text { Being proud: Instructor's praising } \\
\text { of students' ideas }\end{array}$ & $\begin{array}{l}\text { Being content: } \\
\text { Not leaving the lecture though the } \\
\text { content is difficult }\end{array}$ \\
\hline Cognitive & $\begin{array}{l}\text { Being happy: Other students } \\
\text { assisting one in presenting an idea }\end{array}$ & $\begin{array}{l}\text { Being content: Answering a } \\
\text { question posed by the instructor }\end{array}$ & $\begin{array}{l}\text { Being confident: } \\
\text { Understanding the topic }\end{array}$ \\
\hline Affective & $\begin{array}{l}\text { comfort: Another student } \\
\text { expressing enthusiasm of the topic }\end{array}$ & $\begin{array}{l}\text { Being interested: the instructor is } \\
\text { enthusiastic about the content }\end{array}$ & $\begin{array}{c}\text { Not feeling the passing of the time: } \\
\text { The content is interesting }\end{array}$ \\
\hline
\end{tabular}

Table 4. Occurrences in the synchronous lectures that resulted in negative affective engagement

\begin{tabular}{cccc}
\hline & $\begin{array}{c}\text { Interaction between the learner } \\
\text { and other learners }\end{array}$ & $\begin{array}{c}\text { Interaction between the learner and } \\
\text { the instructor }\end{array}$ & $\begin{array}{c}\text { Interaction between the learner and } \\
\text { content }\end{array}$ \\
\hline Behavioural & $\begin{array}{c}\text { Anger: Other students sending } \\
\text { messages to the one who presents } \\
\text { ideas to distract her attention }\end{array}$ & $\begin{array}{c}\text { Discomfort: Not being able to see the } \\
\text { expressions of the instructor }\end{array}$ & $\begin{array}{c}\text { Anger: The inability to follow the } \\
\text { content because of technical } \\
\text { difficulties }\end{array}$ \\
Cognitive & $\begin{array}{c}\text { Anger: A student intolerance for his } \\
\text { classmates' opposing ideas }\end{array}$ & $\begin{array}{c}\text { Sadness: instructor's argument against } \\
\text { a student's idea }\end{array}$ & $\begin{array}{c}\text { Feeling that time is not passing: The } \\
\text { difficulty of the content }\end{array}$ \\
Affective & $\begin{array}{c}\text { Anxiety: Another student expressing } \\
\text { anger because of difficulty in } \\
\text { understanding the content }\end{array}$ & $\begin{array}{c}\text { Being uncomfortable: } \text { The discomfort } \\
\text { of the instructor because of the little } \\
\text { understanding of the topic by the } \\
\text { students }\end{array}$ & $\begin{array}{c}\text { Feeling that time is not passing: The } \\
\text { content is boring }\end{array}$ \\
\hline
\end{tabular}

Table 3 shows the percentages of units related to positive and negative affective engagement exhibited in the synchronous lectures, according to the interaction type and the engagement type. 
Table 5. Percentages of positive and negative affective engagement in synchronous lectures $(\mathrm{N}=402$ units).

\begin{tabular}{|c|c|c|c|c|c|c|c|}
\hline & \multicolumn{2}{|c|}{$\begin{array}{c}\begin{array}{l}\text { Interaction between the } \\
\text { learners }\end{array} \\
\end{array}$} & \multicolumn{2}{|c|}{$\begin{array}{l}\text { Interaction between the learner } \\
\text { and the instructor }\end{array}$} & \multicolumn{2}{|c|}{$\begin{array}{l}\text { Interaction between the } \\
\text { learner and the content }\end{array}$} & \multirow{2}{*}{$\begin{array}{l}\text { Overall } \\
12.19 \%\end{array}$} \\
\hline & $\begin{array}{l}\text { Behavioural } \\
\text { engagement }\end{array}$ & $1 \%$ & $\begin{array}{l}\text { Behavioural } \\
\text { engagement }\end{array}$ & $9.95 \%$ & $\begin{array}{l}\text { Behavioural } \\
\text { engagement }\end{array}$ & $1.24 \%$ & \\
\hline \multirow[t]{4}{*}{$\begin{array}{l}\text { Positive affective } \\
\text { engagement }\end{array}$} & $\begin{array}{l}\text { Cognitive } \\
\text { engagement }\end{array}$ & $1 \%$ & $\begin{array}{l}\text { Cognitive } \\
\text { engagement }\end{array}$ & $21.89 \%$ & $\begin{array}{c}\text { Cognitive } \\
\text { engagement }\end{array}$ & $20.39 \%$ & $43.28 \%$ \\
\hline & $\begin{array}{c}\text { Affective } \\
\text { engagement }\end{array}$ & $1.99 \%$ & $\begin{array}{c}\text { Affective } \\
\text { engagement }\end{array}$ & $2.49 \%$ & $\begin{array}{c}\text { Affective } \\
\text { engagement }\end{array}$ & $8.46 \%$ & $12.94 \%$ \\
\hline & Overall positive & $3.99 \%$ & Overall positive & $34.33 \%$ & $\begin{array}{l}\text { Overall } \\
\text { positive }\end{array}$ & $30.09 \%$ & $68.41 \%$ \\
\hline & $\begin{array}{l}\text { Behavioural } \\
\text { engagement }\end{array}$ & $1.24 \%$ & $\begin{array}{l}\text { Behavioural } \\
\text { engagement }\end{array}$ & $1.24 \%$ & $\begin{array}{l}\text { Behavioural } \\
\text { engagement }\end{array}$ & $4.48 \%$ & $6.96 \%$ \\
\hline \multirow[t]{3}{*}{$\begin{array}{l}\text { Negative affective } \\
\text { engagement }\end{array}$} & $\begin{array}{l}\text { Cognitive } \\
\text { engagement }\end{array}$ & $1.99 \%$ & $\begin{array}{c}\text { Cognitive } \\
\text { engagement }\end{array}$ & $1.49 \%$ & $\begin{array}{c}\text { Cognitive } \\
\text { engagement }\end{array}$ & $19.90 \%$ & $23.38 \%$ \\
\hline & $\begin{array}{c}\text { Affective } \\
\text { engagement }\end{array}$ & $0.50 \%$ & $\begin{array}{c}\text { Affective } \\
\text { engagement }\end{array}$ & $0.50 \%$ & $\begin{array}{c}\text { Affective } \\
\text { engagement }\end{array}$ & $0.25 \%$ & $1.25 \%$ \\
\hline & Overall negative & $3.73 \%$ & Overall negative & $3.23 \%$ & $\begin{array}{c}\text { Overall } \\
\text { negative }\end{array}$ & $24.63 \%$ & $31.59 \%$ \\
\hline
\end{tabular}

Table 3 shows that in the synchronous lectures, students experienced more positive affective engagement (68.41\%) than negative one (31.59\%). Butz, Stupnisky and Pekrun [51] found that emotions are significantly related to students' perceived success for both programme achievement and technology use. Hence students experiencing more positive affective engagement than a negative one shows that they considered their experience of learning through synchronous lecture successful. This indicates that online courses can be a rich environment to foster students' positive affective engagement.

Table 3 shows that the type of interaction occurring in the synchronous lectures has contributed to the students' positive affective engagement differently, with the learner-instructor interaction ranking first with (34.33\%). This finding is in line with Sheridan and Kelly [52] results, who found that students were likely to be motivated if they clearly understood from the instructor what is expected of them. Coming second in giving rise to students' positive affective engagement is the learner-content interaction with (30.09\%). finally, the learner-leaner interaction had the least influence on generating students' positive affective engagement with a mere (3.99\%), exhibiting a significant drop from the other two types of interaction discussed earlier. These results are particularly in conformity with Martin and Bolliger [24] results, who reported having the same order for the contribution of the three types of interaction to the engagement of university students in online learning.

Although the learner-content interaction came second in contributing to the positive affective engagement of students, it came first in contributing to the negative affective engagement of the students in the synchronous lectures with (24.63\%). The results indicate that the learner-content interaction gives rise to positive affective engagement, which is consistent with Nwankwo [53] who reported that students emphasized the interaction they had with course content as the most important out of the three types of interaction. This view is also echoed in Galy, Downey and Johnson [54] conclusion that learner-content interaction plays the most important role in ensuring that online students are successful. While Nistor and Neubauer [55] stated that learner-content is the most important factor in the successful implementation of an online program.

The importance that the students put on content, especially in online setting, is also behind the influence of learnercontent interaction on students' negative affective engagement. When encountering difficulties with the content; which are in the present research mainly cognitive ones, students experience negative affective engagement. Researchers emphasize that it is important for course activities to be structured and clear to understand ([24], [40]), and designed in a way to evoke inquiry and exploration [42]. When the activities do not satisfy the previous characteristics, students can experience affective disengage or negative affective engagement.

Table 3 shows that cognitive engagement was the most contributing factor to the affective engagement of students, whether positive affective engagement $(43.28 \%)$ or negative one $(19.90 \%)$; i.e. $63.18 \%$ overall impact of the cognitive engagement on the affective engagement. This high percentage shows the importance of facilitating content for students, even for university students, through different means. This is in line with Revere and Kovach [56] who recommend making the content come alive through using appropriate technology, which would enhance students' engagement. In the present online course, an attempt was done to facilitate content through the grouping of students through the use of Zoom's rooms. This grouping contributed to the cognitive engagement of the learner with the content and which resulted in $20.39 \%$ of the positive affective engagement of the learner in the context of the synchronous lectures. This also agrees with with Khosa and Volet [57] who found that group engagement could facilitate cognitive activity and metacognitive regulation through collaborative learning. In addition to the above, this impact of the cognitive engagement and processes on their affective engagement and processes has been indicated in previous studies (e.g., [58-60]). 


\section{5-2- Assignments}

Tables 4 and 5 show, respectively, examples of occurrences that resulted in positive and negative affective engagement occurring in the assignments.

Table 6. Occurrences in the assignments that resulted in a positive affective engagement.

\begin{tabular}{|c|c|c|c|}
\hline & $\begin{array}{l}\text { Interaction between the learner } \\
\text { and other learners }\end{array}$ & $\begin{array}{l}\text { Interaction between the learner and } \\
\text { the teacher }\end{array}$ & $\begin{array}{c}\text { Interaction between the learner and } \\
\text { content }\end{array}$ \\
\hline Behavioural & $\begin{array}{l}\text { Enjoying the solving: Collaboration } \\
\text { between the group's members }\end{array}$ & $\begin{array}{l}\text { Being content: The instructor's } \\
\text { explanation of the assignment } \\
\text { conditions }\end{array}$ & $\begin{array}{l}\text { Being satisfied: Working hard on an } \\
\text { assignment }\end{array}$ \\
\hline Cognitive & $\begin{array}{l}\text { Being enthusiastic: Discussing the } \\
\text { solution strategy }\end{array}$ & $\begin{array}{l}\text { Being confident: The instructor's } \\
\text { positive evaluation of the solution }\end{array}$ & $\begin{array}{l}\text { Being confident: Reflecting upon the } \\
\text { solution }\end{array}$ \\
\hline Affective & $\begin{array}{l}\text { Enjoying the work: The entertaining } \\
\text { aspect of working in a group }\end{array}$ & $\begin{array}{l}\text { Being pleased: the instructor humorous } \\
\text { answer to a learner's question }\end{array}$ & $\begin{array}{l}\text { Being enthusiastic: The assignment is } \\
\text { intriguing }\end{array}$ \\
\hline
\end{tabular}

Table 7. Occurrences in the assignments that resulted in a negative affective engagement.

\begin{tabular}{llll}
\hline & $\begin{array}{c}\text { Interaction between the learner and } \\
\text { other learners }\end{array}$ & $\begin{array}{c}\text { Interaction between the learner and } \\
\text { the teacher }\end{array}$ & $\begin{array}{c}\text { Interaction between the learner and } \\
\text { content }\end{array}$ \\
\hline Behavioural & $\begin{array}{l}\text { Frustration: The group members do } \\
\text { not listen to the ideas of one of them }\end{array}$ & Sadness: Instructor's responsiveness & $\begin{array}{l}\text { Anxiety: Not being able to finish the } \\
\text { assignment on time }\end{array}$ \\
Cognitive & $\begin{array}{l}\text { Angriness: Unacceptance of one's } \\
\text { approach to solving the assignment }\end{array}$ & $\begin{array}{l}\text { Sadness: the instructor's negative } \\
\text { feedback on the assignment or part of it }\end{array}$ & $\begin{array}{l}\text { Discomfort: the difficulty to approach } \\
\text { the solving of an assignment }\end{array}$ \\
Affective & $\begin{array}{l}\text { Discomfort: One of the group's } \\
\text { members was anxious during the } \\
\text { solution of the assignment }\end{array}$ & $\begin{array}{l}\text { Being unpleased: the instructor sarcastic } \\
\text { answer to a learner's question }\end{array}$ & $\begin{array}{l}\text { Feeling that time is not passing: The } \\
\text { assignment is not interesting }\end{array}$ \\
\hline
\end{tabular}

Table 6 describes the percentages of units related to positive and negative affective engagement in the assignment solution, according to the interaction type and the engagement type.

Table 8. Percentages of positive and negative affective engagement in assignment work ( $N=386$ units).

\begin{tabular}{|c|c|c|c|c|c|c|c|}
\hline & \multicolumn{2}{|c|}{$\begin{array}{l}\text { Interaction between the } \\
\text { learners }\end{array}$} & \multicolumn{2}{|c|}{$\begin{array}{l}\text { Interaction between the } \\
\text { learner and the teacher }\end{array}$} & \multicolumn{2}{|c|}{$\begin{array}{l}\text { Interaction between the } \\
\text { learner and the content }\end{array}$} & \multirow{2}{*}{$\begin{array}{l}\text { Overall } \\
34.71 \%\end{array}$} \\
\hline \multirow{4}{*}{$\begin{array}{c}\text { Positive } \\
\text { affective } \\
\text { engagement }\end{array}$} & $\begin{array}{l}\text { Behavioural } \\
\text { engagement }\end{array}$ & $16.84 \%$ & $\begin{array}{l}\text { Behavioural } \\
\text { engagement }\end{array}$ & $2.07 \%$ & $\begin{array}{l}\text { Behavioural } \\
\text { engagement }\end{array}$ & $15.80 \%$ & \\
\hline & $\begin{array}{l}\text { Cognitive } \\
\text { engagement }\end{array}$ & $10.88 \%$ & $\begin{array}{l}\text { Cognitive } \\
\text { engagement }\end{array}$ & $8.81 \%$ & $\begin{array}{l}\text { Cognitive } \\
\text { engagement }\end{array}$ & 2.33 & $22.02 \%$ \\
\hline & $\begin{array}{c}\text { Affective } \\
\text { engagement }\end{array}$ & $5.44 \%$ & $\begin{array}{c}\text { Affective } \\
\text { engagement }\end{array}$ & $0.78 \%$ & $\begin{array}{c}\text { Affective } \\
\text { engagement }\end{array}$ & $7.25 \%$ & $13.47 \%$ \\
\hline & Overall positive & $33.16 \%$ & $\begin{array}{l}\text { Overall } \\
\text { positive }\end{array}$ & $11.66 \%$ & $\begin{array}{l}\text { Overall } \\
\text { positive }\end{array}$ & $25.38 \%$ & $70.20 \%$ \\
\hline \multirow{4}{*}{$\begin{array}{c}\text { Negative } \\
\text { affective } \\
\text { engagement }\end{array}$} & $\begin{array}{l}\text { Behavioural } \\
\text { engagement }\end{array}$ & $4.15 \%$ & $\begin{array}{l}\text { Behavioural } \\
\text { engagement }\end{array}$ & $2.85 \%$ & $\begin{array}{l}\text { Behavioural } \\
\text { engagement }\end{array}$ & $5.44 \%$ & $12.44 \%$ \\
\hline & $\begin{array}{l}\text { Cognitive } \\
\text { engagement }\end{array}$ & $3.89 \%$ & $\begin{array}{l}\text { Cognitive } \\
\text { engagement }\end{array}$ & $4.15 \%$ & $\begin{array}{c}\text { Cognitive } \\
\text { engagement }\end{array}$ & $3.63 \%$ & $11.67 \%$ \\
\hline & $\begin{array}{c}\text { Affective } \\
\text { engagement }\end{array}$ & $0.78 \%$ & $\begin{array}{c}\text { Affective } \\
\text { engagement }\end{array}$ & $0.25 \%$ & $\begin{array}{c}\text { Affective } \\
\text { engagement }\end{array}$ & $4.66 \%$ & $5.69 \%$ \\
\hline & Overall negative & $8.82 \%$ & $\begin{array}{c}\text { Overall } \\
\text { negative }\end{array}$ & $7.25 \%$ & $\begin{array}{c}\text { Overall } \\
\text { negative }\end{array}$ & $13.73 \%$ & $29.80 \%$ \\
\hline
\end{tabular}

Table 6 shows that while doing the assignments, the students experienced more positive affective engagement $(70.20 \%)$ than negative one $(29.80 \%)$. One of the main reasons for this is students working in groups on those assignments. Group work causes students to feel as being part of a community; a small one in this case. Feeling part of a community could influence students' affective engagement positively [61].

Table 6 also shows that while working on these assignments, the learner-learner interaction (33.16\%) came first in contributing to the positive affective engagement of the learner, followed by learner-content interaction $(25.38 \%)$. Moreover, the smallest contribution to the positive affective engagement of the students in the synchronous lectures came from the learner-instructor interaction (11.66\%). These results indicate the importance and value that university students place on group work while working on assignments. The results support other studies that reported the positive role of group work in facilitating students' learning. Hammar Chiriac [62] found that the students reported that most of their experiences with group work facilitated their learning, especially in the area of academic knowledge. In addition, Shaw, Mitchell and Del Fabbro [63] reported that students found class discussions and sharing experiences have positively influenced their learning and facilitated their exchange of knowledge about international issues related to their speciality. 
As a facilitator of students' learning, group work could lessen the negative engagement of the group members, as negative engagement could occur due to the negative interaction of the group members [64]. In the present research, the negative affective engagement of the students was reported at $8.82 \%$ of the overall statements related to affective engagement in the group work on assignments; i.e. the learner-learner interaction in assignments. This percentage is relatively not high, but focusing more attention on the factors that cause it could lessen their occurrences and thus lessen the negative affective engagement of the students in their work on online assignments. This could be done by stressing the importance of negotiation and alignment in group work [65, 66], which would lead to understanding of the mechanism of group work and thus utilize this mechanism in this group work. In detail, Baya et al. [65] found that prospective teachers used negotiation, in the context of a community of practice, as an escalator that supports the decision of in-service mathematics teachers to integrate ICT in the mathematics classroom. Furthermore, Daher et al. [66] found that the negotiation processes supported the development of the prospective teachers' meta-cognitive processes in solving mathematics-based programming problems in the Scratch environment.

\section{5-3- Forums}

Tables 7 and 8 show, respectively, examples of occurrences that resulted in positive and negative affective engagement in forums.

Table 9. Occurrences in forums that resulted in a positive affective engagement.

\begin{tabular}{llll}
\hline & $\begin{array}{c}\text { Interaction between the learner and } \\
\text { other learners }\end{array}$ & $\begin{array}{l}\text { Interaction between the learner and } \\
\text { the teacher }\end{array}$ & $\begin{array}{c}\text { Interaction between the learner and } \\
\text { content }\end{array}$ \\
\hline Behavioural & $\begin{array}{l}\text { Being content: Knowing the conditions } \\
\text { of students' interactions in the forum }\end{array}$ & $\begin{array}{l}\text { Being satisfied: The instructor's positive } \\
\text { feedback }\end{array}$ & $\begin{array}{l}\text { Being content: Knowing the conditions of } \\
\text { students' first post to the forum }\end{array}$ \\
Cognitive & $\begin{array}{l}\text { Being enthusiastic: Discussing the } \\
\text { correctness of another student's answer }\end{array}$ & $\begin{array}{l}\text { Being content: The instructor's } \\
\text { student is indeed critical Being interested: Multiple ideas related on }\end{array}$ \\
Affective & $\begin{array}{l}\text { Enjoying the interaction in the forum: } \\
\text { The entertaining aspect of discussing } \\
\text { each other's ideas according to their } \\
\text { criticality }\end{array}$ & $\begin{array}{l}\text { Being content: The pleasant way of the } \\
\text { instructor in giving feedback on } \\
\text { students' contributions }\end{array}$ & $\begin{array}{l}\text { Enthusiasm: } \text { The idea in the post to the } \\
\text { forum was interesting }\end{array}$ \\
\hline
\end{tabular}

Table 10. Occurrences in forums that resulted in a negative affective engagement.

\begin{tabular}{llll}
\hline & $\begin{array}{c}\text { Interaction between the learner and } \\
\text { other learners }\end{array}$ & $\begin{array}{l}\text { Interaction between the learner and } \\
\text { the teacher }\end{array}$ & $\begin{array}{c}\text { Interaction between the learner and } \\
\text { content }\end{array}$ \\
\hline Behavioural & $\begin{array}{l}\text { Discomfort:Students' negative } \\
\text { responsiveness on comments }\end{array}$ & $\begin{array}{l}\text { Frustration: The long time it took the } \\
\text { instructor to respond on the students' } \\
\text { contribution in the forum }\end{array}$ & $\begin{array}{l}\text { Discontent: the inability to devote enough } \\
\text { time to read the posts to the forum }\end{array}$ \\
Cognitive & $\begin{array}{l}\text { Frustration: The misunderstanding of } \\
\text { one's idea by another student }\end{array}$ & $\begin{array}{l}\text { Discomfort: Requests from students in } \\
\text { the instructor's comments }\end{array}$ & $\begin{array}{l}\text { Boredom: Knowledge level of students' } \\
\text { posts to the forum }\end{array}$ \\
Affective & $\begin{array}{l}\text { Angriness: the angry way in which one } \\
\text { learner replied to another learner }\end{array}$ & $\begin{array}{l}\text { Angriness: the disinterest with which } \\
\text { the instructor replied to a learner }\end{array}$ & $\begin{array}{l}\text { Boredom: The idea in the post to the } \\
\text { forum was not interesting }\end{array}$ \\
\hline
\end{tabular}

Table 9 describes the percentages of units related to positive and negative affective engagement in forums, according to the interaction type and the engagement type.

Table 11. Percentages of positive and negative affective engagement in forums ( $N=364$ units).

\begin{tabular}{|c|c|c|c|c|c|c|c|}
\hline & \multicolumn{2}{|c|}{$\begin{array}{c}\text { Interaction between the } \\
\text { learners }\end{array}$} & \multicolumn{2}{|c|}{$\begin{array}{c}\text { Interaction between the learner } \\
\text { and the instructor }\end{array}$} & \multicolumn{2}{|c|}{$\begin{array}{c}\text { Interaction between the learner } \\
\text { and the content }\end{array}$} & \multirow{2}{*}{$\begin{array}{l}\text { Overall } \\
23.36 \%\end{array}$} \\
\hline \multirow{3}{*}{$\begin{array}{c}\text { Positive } \\
\text { affective } \\
\text { engagement }\end{array}$} & $\begin{array}{l}\text { Behavioural } \\
\text { engagement }\end{array}$ & $6.87 \%$ & $\begin{array}{l}\text { Behavioural } \\
\text { engagement }\end{array}$ & $11.54 \%$ & $\begin{array}{l}\text { Behavioural } \\
\text { engagement }\end{array}$ & $4.95 \%$ & \\
\hline & $\begin{array}{l}\text { Cognitive } \\
\text { engagement }\end{array}$ & $8.24 \%$ & Cognitive engagement & $12.91 \%$ & $\begin{array}{l}\text { Cognitive } \\
\text { engagement }\end{array}$ & $9.34 \%$ & $30.49 \%$ \\
\hline & $\begin{array}{c}\text { Affective } \\
\text { engagement }\end{array}$ & $5.77 \%$ & Affective engagement & $5.22 \%$ & Affective engagement & $5.49 \%$ & $16.48 \%$ \\
\hline \multirow{5}{*}{$\begin{array}{c}\text { Negative } \\
\text { affective } \\
\text { engagement }\end{array}$} & Overall positive & $20.88 \%$ & Overall positive & $29.67 \%$ & Overall positive & $19.78 \%$ & $70.33 \%$ \\
\hline & $\begin{array}{l}\text { Behavioural } \\
\text { engagement }\end{array}$ & $5.22 \%$ & $\begin{array}{l}\text { Behavioural } \\
\text { engagement }\end{array}$ & $1.37 \%$ & $\begin{array}{l}\text { Behavioural } \\
\text { engagement }\end{array}$ & $5.49 \%$ & $12.08 \%$ \\
\hline & $\begin{array}{c}\text { Cognitive } \\
\text { engagement }\end{array}$ & $3.85 \%$ & Cognitive engagement & $0.84 \%$ & $\begin{array}{l}\text { Cognitive } \\
\text { engagement }\end{array}$ & $6.04 \%$ & $10.73 \%$ \\
\hline & $\begin{array}{c}\text { Affective } \\
\text { engagement }\end{array}$ & $0.82 \%$ & Affective engagement & $0.55 \%$ & Affective engagement & $5.49 \%$ & $6.86 \%$ \\
\hline & Overall negative & $9.89 \%$ & Overall negative & $2.76 \%$ & Overall negative & $17.02 \%$ & $29.67 \%$ \\
\hline
\end{tabular}


Table 9 shows that in the forum discussions, the students experienced more positive affective engagement (70.33\%) than negative one (29.67\%). This finding agree with the view of the researchers who emphasized the role of forums in students' learning [67, 68]. Noroozi et al. [69] argued that online discussion forums could enable flexible and independent learning and knowledge construction, while Zhang [70] argued that forums could develop critical thinking. It is expected that the various potentialities of forums would cause affective response, whether negative or positive. Where positive affect would result from the potentialities of forums; potentialities that were pointed at above. In addition, Harris and Sandor [71] asserted that online forums can engage students in the online learning process, by advocating an active and central role of the students. This active and central role is evident mainly through the positive cognitive engagement in the forums (30.49\%) and the positive behavioural engagement in these forums $(23.36 \%)$. On the other hand, the 3 types of interaction in the forums contribute negatively to students' affective engagement mainly through cognitive (10.73\%) and behavioural (12.08\%) engagement.

Table 9 shows that in the discussions on the forums, the learner-instructor interaction $(29.67 \%)$ came first in contributing to the positive affective engagement of the learner, then the learner-learner interaction $(20.88 \%)$ and the learner-content interaction (19.78\%) with almost similar percentages. These results indicate the importance and value that university students place on the learner-instructor interaction in the forum, where the facilitation of discussion is needed. These results are in conformity with Anderson et al. [72] who argued that the instructor's facilitation of discourse during the course is critical to maintaining positive affective engagement, such as interest and motivation. In addition, Shea et al. [73] found that the teaching presence contributed to students' sense of trust, collaboration, shared educational objectives, support, and learning.

\section{6- Summary and Conclusion}

Teaching and learning online courses and their relationship with other educational aspects are attracting the attention of researchers as they facilitate students' learning [74, 75], especially in COVID19 Pandemic [76-78]. In the present research, we intended to study the affective engagement of higher education students in online courses. The research results indicated that the students experienced both positive and negative affective engagement in the three communicational channels of online learning: synchronous lectures, forums and assignments. We suggest looking at the positive and negative occurrences of affective engagement in online courses as happening in a space with three dimensions: type of interaction (learner-learner, learner-teacher and learner-content), type of engagement (behavioural, cognitive and affective) and communication channel (synchronous lectures, assignments and forums).

In the present research, we considered how the combination of two dimensions (type of interaction and type of engagement) impacts students' engagement in the third dimension (communication channels). Looking at the affective engagement in online courses as occurring in a three-dimensional space has enabled us to look at specific cells in the space as they impact the occurrences of positive and negative affective engagement. The cognitive engagement in the learner-instructor and learner-content interactions in the context of synchronous lectures resulted in more positive affective engagement of the students than other combinations of conditions in the synchronous lectures. This was not the case in the assignment context, where the behavioural engagement in the learner-learner and learner-content interactions resulted in more positive affective engagement of the students than other combinations of conditions in the assignment context. The case of the forum context was similar to the synchronous lectures in that the combination of the cognitive engagement and the learner-instructor interaction has resulted in more positive affective engagement of the students than other combinations of conditions in the forum context. In addition, the combination of the behavioural engagement and the learner-instructor interaction has resulted also in more positive affective engagement of the students than other combinations of conditions in the forum context.

In the present study, we considered the learners' affective engagement as an outcome variable and examined the interaction type and the engagement type and their combination as predicting variables. This is one limitation of the study. Future studies are needed where the outcome variable could be learners' cognitive engagement or learners' behavioural engagement. The combination of the predicting variables would enrich our understanding of factors that could influence the different types of students' engagement in online settings.

A second limitation of the study is the size of sample, as the present research examined the engagement of 19 university students who participated in an educational distance learning course. Future research is needed to consider students' engagement in additional educational courses, especially courses intended for a high number of participants like MOOCs. A third limitation of the study is the type of course in which it was carried out; i.e. educational course. Future research is needed to study students' engagement in university courses in general. This future research would reveal the characteristics of engagement in three main channels of distance learning courses: synchronous lectures, assignments, and forums. 


\section{7- Declarations}

\section{7-1-Author Contributions}

All authors contributed to the design and implementation of the research, to the analysis of the results, and to the writing of the manuscript. All authors have read and agreed to the published version of the manuscript.

\section{7-2-Data Availability Statement}

The data presented in this study are available on request from the corresponding author.

\section{7-3- Funding}

The author received no financial support for the research, authorship, and/or publication of this article.

\section{7-4- Ethical Approval}

Participants gave their written consent to use their anonymous data for research purposes.

\section{7-5- Conflicts of Interest}

The author declares that there is no conflict of interest regarding the publication of this manuscript. In addition, the ethical issues, including plagiarism, informed consent, misconduct, data fabrication and/or falsification, double publication and/or submission, and redundancies have been completely observed by the author.

\section{8- References}

[1] Kuh, George D. "What we're learning about student engagement from NSSE: Benchmarks for effective educational practices." Change: The Magazine of Higher Learning 35, no. 2 (2003): 24-32. doi:10.1080/00091380309604090.

[2] Pascarella, Ernest T., Tricia A. Seifert, and Charles Blaich. "How Effective Are the NSSE Benchmarks in Predicting Important Educational Outcomes?" Change: The Magazine of Higher Learning 42, no. 1 (January 2010): 16-22. doi:10.1080/00091380903449060.

[3] Jones, Carla E., and John D. Watt. "Psychosocial development and moral orientation among traditional-aged college students." Journal of College Student Development (1999): 125-132.

[4] Kuh, George D., Jillian Kinzie, John H. Schuh, and Elizabeth J. Whitt. "Never Let It Rest Lessons About Student Success from High-Performing Colleges and Universities." Change: The Magazine of Higher Learning 37, no. 4 (July 2005): 44-51. doi:10.3200/chng.37.4.44-51.

[5] Kuh, George D., Ty M. Cruce, Rick Shoup, Jillian Kinzie, and Robert M. Gonyea. "Unmasking the Effects of Student Engagement on First-Year College Grades and Persistence.” The Journal of Higher Education 79, no. 5 (September 2008): 540-563. doi:10.1080/00221546.2008.11772116.

[6] Bengtsson, Mariette. "How to Plan and Perform a Qualitative Study Using Content Analysis.” NursingPlus Open 2 (2016): 8-14. doi:10.1016/j.npls.2016.01.001.

[7] Wang, Zhijun, Li Chen, and Terry Anderson. "A Framework for Interaction and Cognitive Engagement in Connectivist Learning Contexts." The International Review of Research in Open and Distributed Learning 15, no. 2 (April 1, 2014): 121-141. doi:10.19173/irrodl.v15i2.1709.

[8] Endo, Jean J., and Richard L. Harpel. "The effect of student-faculty interaction on students' educational outcomes." Research in Higher Education 16, no. 2 (1982): 115-138. doi:10.1007/BF00973505.

[9] Lareau, Annette, and Erin McNamara Horvat. "Moments of Social Inclusion and Exclusion Race, Class, and Cultural Capital in Family-School Relationships.” Sociology of Education 72, no. 1 (January 1999): 37. doi:10.2307/2673185.

[10] Solomonides, Ian. "A relational and multidimensional model of student engagement." The Student Engagement Handbook: Practice in Higher Education (2013): 43-58.

[11] Ben-Eliyahu, Adar, Debra Moore, Rena Dorph, and Christian D. Schunn. "Investigating the Multidimensionality of Engagement: Affective, Behavioral, and Cognitive Engagement across Science Activities and Contexts.” Contemporary Educational Psychology 53 (April 2018): 87-105. doi:10.1016/j.cedpsych.2018.01.002.

[12] Bond, Melissa, Katja Buntins, Svenja Bedenlier, Olaf Zawacki-Richter, and Michael Kerres. "Mapping Research in Student Engagement and Educational Technology in Higher Education: a Systematic Evidence Map." International Journal of Educational Technology in Higher Education 17, no. 1 (January 22, 2020). doi:10.1186/s41239-019-0176-8.

[13] Axelson, Rick D., and Arend Flick. "Defining Student Engagement." Change: The Magazine of Higher Learning 43, no. 1 (December 27, 2010): 38-43. doi:10.1080/00091383.2011.533096. 
[14] Eccles, Jacquelynne S. “Engagement: Where to Next?” Learning and Instruction 43 (June 2016): 71-75. doi:10.1016/j.learninstruc.2016.02.003.

[15] Reschly, Amy L., and Sandra L. Christenson. "Jingle, Jangle, and Conceptual Haziness: Evolution and Future Directions of the Engagement Construct.” Handbook of Research on Student Engagement (2012): 3-19. doi:10.1007/978-1-4614-2018-7_1.

[16] Kahu, Ella R. "Framing Student Engagement in Higher Education.” Studies in Higher Education 38, no. 5 (June 2013): 758773. doi:10.1080/03075079.2011.598505.

[17] Cappella, Elise, Ha Yeon Kim, Jennifer W. Neal, and Daisy R. Jackson. "Classroom Peer Relationships and Behavioral Engagement in Elementary School: The Role of Social Network Equity.” American Journal of Community Psychology 52, no. 3-4 (October 1, 2013): 367-379. doi:10.1007/s10464-013-9603-5.

[18] Fredricks, Jennifer A, Phyllis C Blumenfeld, and Alison H Paris. "School Engagement: Potential of the Concept, State of the Evidence.” Review of Educational Research 74, no. 1 (March 2004): 59-109. doi:10.3102/00346543074001059.

[19] Bond, Melissa, and Svenja Bedenlier. "Facilitating Student Engagement Through Educational Technology: Towards a Conceptual Framework." Journal of Interactive Media in Education 2019, no. 1 (2019). doi:10.5334/jime.528.

[20] Barkley, Elizabeth F., and Claire H. Major. "Student engagement techniques: A handbook for college faculty.” John Wiley \& Sons, (2020).

[21] Glanville, Jennifer L., and Tina Wildhagen. "The Measurement of School Engagement.” Educational and Psychological Measurement 67, no. 6 (June 6, 2007): 1019-1041. doi:10.1177/0013164406299126.

[22] Skinner, Ellen A., and Jennifer R. Pitzer. "Developmental Dynamics of Student Engagement, Coping, and Everyday Resilience.” Handbook of Research on Student Engagement (2012): 21-44. doi:10.1007/978-1-4614-2018-7_2.

[23] Banna, Jinan, Meng-Fen Grace Lin, Maria Stewart, and Marie K. Fialkowski. "Interaction matters: Strategies to promote engaged learning in an online introductory nutrition course." Journal of Online Learning and Teaching/MERLOT 11, no. 2 (2015): 249261.

[24] Martin, Florence, and Doris U Bolliger. "Engagement Matters: Student Perceptions on the Importance of Engagement Strategies in the Online Learning Environment.” Online Learning 22, no. 1 (March 1, 2018): 205-222. doi:10.24059/olj.v22i1.1092.

[25] Kahu, Ella R., and Karen Nelson. "Student Engagement in the Educational Interface: Understanding the Mechanisms of Student Success." Higher Education Research \& Development 37, no. 1 (July 3, 2017): 58-71. doi:10.1080/07294360.2017.1344197.

[26] Haug, James C., Linda Berns Wright, and W. Allen Huckabee. “Undergraduate Business Students' Perceptions about Engagement.” Journal of Education for Business 94, no. 2 (October 2, 2018): 81-91. doi:10.1080/08832323.2018.1504738.

[27] Wiggins, Benjamin L., Sarah L. Eddy, Leah Wener-Fligner, Karen Freisem, Daniel Z. Grunspan, Elli J. Theobald, Jerry Timbrook, and Alison J. Crowe. "ASPECT: A Survey to Assess Student Perspective of Engagement in an Active-Learning Classroom.” Edited by Jennifer Momsen. CBE—Life Sciences Education 16, no. 2 (June 2017): ar32. doi:10.1187/cbe.16-080244 .

[28] Pekrun, Reinhard, and Lisa Linnenbrink-Garcia. "Academic Emotions and Student Engagement." Handbook of Research on Student Engagement (2012): 259-282. doi:10.1007/978-1-4614-2018-7_12.

[29] Halverson, Lisa R., and Charles R. Graham. "Learner Engagement in Blended Learning Environments: A Conceptual Framework.” Online Learning 23, no. 2 (June 1, 2019). doi:10.24059/olj.v23i2.1481.

[30] Skinner, Ellen A., and Michael J. Belmont. "Motivation in the Classroom: Reciprocal Effects of Teacher Behavior and Student Engagement across the School Year.” Journal of Educational Psychology 85, no. 4 (1993): 571-581. doi:10.1037/00220663.85.4.571.

[31] Skinner, Ellen A., Thomas A. Kindermann, and Carrie J. Furrer. "A Motivational Perspective on Engagement and Disaffection." Educational and Psychological Measurement 69, no. 3 (November 14, 2008): 493-525. doi:10.1177/0013164408323233.

[32] Meyer, Katrina A. "Student Engagement in Online Learning: What Works and Why." ASHE Higher Education Report 40, no. 6 (November 2014): 1-114. doi:10.1002/aehe.20018.

[33] Huang, Ronghuai, Ahmed Tlili, Ting-Wen Chang, Xiangling Zhang, Fabio Nascimbeni, and Daniel Burgos. "Disrupted Classes, Undisrupted Learning during COVID-19 Outbreak in China: Application of Open Educational Practices and Resources." Smart Learning Environments 7, no. 1 (July 6, 2020). doi:10.1186/s40561-020-00125-8.

[34] Bedenlier, Svenja, Melissa Bond, Katja Buntins, Olaf Zawacki-Richter, and Michael Kerres. "Facilitating Student Engagement through Educational Technology in Higher Education: A Systematic Review in the Field of Arts and Humanities." Australasian Journal of Educational Technology (January 26, 2020): 126-150. doi:10.14742/ajet.5477. 
[35] Henrie, Curtis R., Lisa R. Halverson, and Charles R. Graham. "Measuring Student Engagement in Technology-Mediated Learning: A Review.” Computers \& Education 90 (December 2015): 36-53. doi:10.1016/j.compedu.2015.09.005.

[36] Howard, Sarah K., Jun Ma, and Jie Yang. "Student Rules: Exploring Patterns of Students' Computer-Efficacy and Engagement with Digital Technologies in Learning." Computers \& Education 101 (October 2016): 29-42. doi:10.1016/j.compedu.2016.05.008.

[37] Kanasa, Harry. "Establishing and Maintaining Rapport in an Online, Higher Education Setting." Student Engagement and Educational Rapport in Higher Education (October 6, 2016): 67-85. doi:10.1007/978-3-319-46034-5_4.

[38] Stavredes, Tina M., and Tiffany M. Herder. "Engaging students in an online environment." Student engagement in higher education: Theoretical perspectives and practical approaches for diverse populations (2015): 257-269.

[39] Bernard, Robert M., Philip C. Abrami, Eugene Borokhovski, C. Anne Wade, Rana M. Tamim, Michael A. Surkes, and Edward Clement Bethel. "A Meta-Analysis of Three Types of Interaction Treatments in Distance Education." Review of Educational Research 79, no. 3 (September 2009): 1243-1289. doi:10.3102/0034654309333844.

[40] Yang, Dazhi. "Instructional Strategies and Course Design for Teaching Statistics Online: Perspectives from Online Students." International Journal of STEM Education 4, no. 1 (December 2017). doi:10.1186/s40594-017-0096-x.

[41] Gaytan, Jorge, and Beryl C. McEwen. "Effective Online Instructional and Assessment Strategies." American Journal of Distance Education 21, no. 3 (September 13, 2007): 117-132. doi:10.1080/08923640701341653.

[42] Stavredes, Tina, and Tiffany Herder. A guide to online course design: Strategies for student success. John Wiley \& Sons, (2014).

[43] Reschly, Amy L., and Sandra L. Christenson. "Jingle, Jangle, and Conceptual Haziness: Evolution and Future Directions of the Engagement Construct.” Handbook of Research on Student Engagement (2012): 3-19. doi:10.1007/978-1-4614-2018-7_1.

[44] Chen, L., R. Zhang, and C. Liu. "Listening Strategy Use and Influential Factors in Web-Based Computer Assisted Language Learning.” Journal of Computer Assisted Learning 30, no. 3 (September 30, 2013): 207-219. doi:10.1111/jcal.12041.

[45] Sun, Pei-Chen, Ray J. Tsai, Glenn Finger, Yueh-Yang Chen, and Dowming Yeh. "What Drives a Successful e-Learning? An Empirical Investigation of the Critical Factors Influencing Learner Satisfaction.” Computers \& Education 50, no. 4 (May 2008): 1183-1202. doi:10.1016/j.compedu.2006.11.007.

[46] Garrison, D. Randy, and Martha Cleveland-Innes. "Facilitating Cognitive Presence in Online Learning: Interaction Is Not Enough.” American Journal of Distance Education 19, no. 3 (September 2005): 133-148. doi:10.1207/s15389286ajde1903_2.

[47] Lee, Jiyeon. "Patterns of interaction and participation in a large online course: Strategies for fostering sustainable discussion." Journal of Educational Technology \& Society 15, no. 1 (2012): 260-272.

[48] Boeije, Hennie. "A purposeful approach to the constant comparative method in the analysis of qualitative interviews." Quality and quantity 36, no. 4 (2002): 391-409. doi:10.1023/A:1020909529486.

[49] Patton, M. Q. “Qualitative research and evaluation methods (3rd ed.)” (2002). Thousand Oaks, CA: Sage.

[50] Bolliger, Doris U., and Florence Martin. "Instructor and Student Perceptions of Online Student Engagement Strategies." Distance Education 39, no. 4 (September 18, 2018): 568-583. doi:10.1080/01587919.2018.1520041.

[51] Butz, Nikolaus T., Robert H. Stupnisky, and Reinhard Pekrun. "Students' Emotions for Achievement and Technology Use in Synchronous Hybrid Graduate Programmes: a Control-Value Approach.” Research in Learning Technology 23 (March 23, 2015). doi:10.3402/rlt.v23.26097.

[52] Sheridan, Kathleen, and Melissa A. Kelly. "The indicators of instructor presence that are important to students in online courses." Journal of Online Learning and Teaching 6, no. 4 (2010): 767-779.

[53] Nwankwo, A. A. "Students' learning experiences and perceptions of online course content and interactions" (Ph. D. Dissertation) (2015). Walden University, Minneapolis, Minnesota.

[54] Galy, Edith, Clara Downey, and Jennie Johnson. "The Effect of Using E-Learning Tools in Online and Campus-Based Classrooms on Student Performance.” Journal of Information Technology Education: Research 10 (2011): $209-230$. doi:10.28945/1503.

[55] Nistor, Nicolae, and Katrin Neubauer. "From Participation to Dropout: Quantitative Participation Patterns in Online University Courses.” Computers \& Education 55, no. 2 (September 2010): 663-672. doi:10.1016/j.compedu.2010.02.026.

[56] Revere, Lee, and Jamison V. Kovach. "Online Technologies for Engaged Learning a Meaningful Synthesis for Educators." Quarterly Review of Distance Education 12, no. 2 (2011):113-124.

[57] Khosa, Deep K., and Simone E. Volet. "Productive Group Engagement in Cognitive Activity and Metacognitive Regulation During Collaborative Learning: Can It Explain Differences in Students' Conceptual Understanding?” Metacognition and Learning 9, no. 3 (May 27, 2014): 287-307. doi:10.1007/s11409-014-9117-z. 
[58] Daher, Wajeeh. "Discursive Positionings and Emotions in Modelling Activities." International Journal of Mathematical Education in Science and Technology 46, no. 8 (April 18, 2015): 1149-1164. doi:10.1080/0020739x.2015.1031836.

[59] Daher, Wajeeh. "Students' Positioning and Emotions in Learning Geometric Definition." Journal on Mathematics Education 11, no. 1 (2020): 111-134.

[60] Daher, Wajeeh, Ahlam Anabousy, and Roqaya Jabarin. "Metacognition, Positioning and Emotions in Mathematical Activities." International Journal of Research in Education and Science (January 24, 2018): 292-303. doi:10.21890/ijres.383184.

[61] Hewson, Edmund R. F. "Students' Emotional Engagement, Motivation and Behaviour over the Life of an Online Course: Reflections on Two Market Research Case Studies.” Journal of Interactive Media in Education 2018, no. 1 (2018). doi:10.5334/jime.472.

[62] Hammar Chiriac, Eva. "Group Work as an Incentive for Learning -Students' Experiences of Group Work." Frontiers in Psychology 5 (June 5, 2014). doi:10.3389/fpsyg.2014.00558.

[63] Shaw, Julie, Creina Mitchell, and Letitia Del Fabbro. "Group Work: Facilitating the Learning of International and Domestic Undergraduate Nursing Students.” Education for Health 28, no. 2 (2015): 124. doi:10.4103/1357-6283.170123.

[64] Alfares, Nurah. "Benefits and Difficulties of Learning in Group Work in EFL Classes in Saudi Arabia." English Language Teaching 10, no. 7 (June 18, 2017): 247. doi:10.5539/elt.v10n7p247.

[65] Baya, Nimer, Wajeeh Daher, and Ahlam Anabousy. "The Development of In-Service Mathematics Teachers' Integration of ICT in a Community of Practice: Teaching-in-Context Theory." International Journal of Emerging Technologies in Learning 14, no. 1 (2019):125. doi: 10.3991/ijet.v14i01.9134

[66] Daher, Wajeeh, Nimer Baya'a, Otman Jaber, and Juhaina Awawdeh Shahbari. “A Trajectory for Advancing the Meta-Cognitive Solving of Mathematics-Based Programming Problems with Scratch.” Symmetry 12, no. 10 (October 2, 2020 ): 1627. doi:10.3390/sym12101627.

[67] Daher, Wajeeh. "Virtual Interactions in Distance Learning." Handbook of Research on Practices and Outcomes in Virtual Worlds and Environments, IGI Global. (2012): 514-535. doi:10.4018/978-1-60960-762-3.ch028.

[68] Daher, Wajeeh, and Juhaina Awawdeh Shahbari. "Secondary Students' Identities in the Virtual Classroom.” Sustainability 12, no. 11 (May 28, 2020): 4407. doi:10.3390/su12114407.

[69] Noroozi, Omid, Armin Weinberger, Harm J.A. Biemans, Martin Mulder, and Mohammad Chizari. "Facilitating Argumentative Knowledge Construction through a Transactive Discussion Script in CSCL.” Computers \& Education 61 (February 2013): 5976. doi:10.1016/j.compedu.2012.08.013.

[70] Zhang, Jianwei, Marlene Scardamalia, Mary Lamon, Richard Messina, and Richard Reeve. "Socio-Cognitive Dynamics of Knowledge Building in the Work of 9- and 10-Year-Olds.” Educational Technology Research and Development 55, no. 2 (September 27, 2006): 117-145. doi:10.1007/s11423-006-9019-0.

[71] Harris, N. and Sandor, M. "Developing online discussion forums as student centred peer e-learning environments. In: ICT: Providing Choices for Learners and Learning”. Proceedings Ascilite Singapore (2007): 383-387.

[72] Anderson, T., Rourke, L., Garrison, D. R., and Archer, W. Assessing teaching presence in a computer conferencing context. Journal of Asynchronous Learning Networks, 5, no. 2 (2001).

[73] Shea, Peter, Chun Sau Li, and Alexandra Pickett. "A Study of Teaching Presence and Student Sense of Learning Community in Fully Online and Web-Enhanced College Courses.” The Internet and Higher Education 9, no. 3 (July 2006): 175-190. doi:10.1016/j.iheduc.2006.06.005.

[74] Damuluri, SriUdaya, Khondkar Islam, Pouyan Ahmadi, and Namra Shafiq Qureshi. "Analyzing Navigational Data and Predicting Student Grades Using Support Vector Machine.” Emerging Science Journal 4, no. 4 (August 1, 2020): $243-252$. doi:10.28991/esj-2020-01227.

[75] Aristika, Ayu, . Darhim, Dadang Juandi, and. Kusnandi. "The Effectiveness of Hybrid Learning in Improving of Teacher-Student Relationship in Terms of Learning Motivation.” Emerging Science Journal 5, no. 4 (August 1, 2021): 443-456. doi:10.28991/esj2021-01288.

[76] Antonopoulou, Hera, Constantinos Halkiopoulos, Olympia Barlou, and Grigorios N. Beligiannis. "Transformational Leadership and Digital Skills in Higher Education Institutes: During the COVID-19 Pandemic.” Emerging Science Journal 5, no. 1 (February 1, 2021): 1-15. doi:10.28991/esj-2021-01252.

[77] Lajčin, Daniel, and Dáša Porubčanová. “Teamwork during the COVID-19 Pandemic.” Emerging Science Journal 5 (April 19, 2021): 1-10. doi:10.28991/esj-2021-sper-01.

[78] Grinberga Zalite, Gunta, and Andra Zvirbule. "Digital Readiness and Competitiveness of the EU Higher Education Institutions: The COVID-19 Pandemic Impact.” Emerging Science Journal 4, no. 4 (August 1, 2020): 297-304. doi:10.28991/esj-202001232. 